\title{
New evidence for Hercynian faulting in the southernmost margin of the Rharb Basin (Morocco)
}

\author{
Nouvelles preuves du rejeu des failles hercyniennes sur la \\ bordure méridionale du bassin du Rharb (Maroc) \\ Lahcen Zouhri \\ Département Géosciences, Institut Polytechnique \\ LaSalle Beauvais, La Salle Beauvais \\ Daniel Vachard, Christian Lamouroux \\ Université de Lille I \\ USTL, Villeneuve d'Ascq
}

The Miocene-Pliocene Rharb Basin has important groundwater and hydrocarbon potential in western Morocco. The Pliocene-Quaternary reservoir rests upon the Miocene-Pliocene marly units. The paleogeographic limits are based on planktonic foraminifera biozones. They contributed to the geometric reconstruction of this basin. The goal of the present study is to establish the paleogeographic evolution of the Rharb Basin and the Hercynian structures deduced from seismic and gravity data interpretation. The Pliocene-Quaternary deposits exhibit thickness and lateral facies variations. The Pliocene bathyal gulf showed several tectonic phases, marked by the westward migration of the paleogeographic limit in its eastern part, and a southward migration from its northern one. During Miocene-Pliocene times, the tectonic activity within the study area is characterized by extensional and compressional structures. The faults affecting the Paleozoic units were reactivated several times. The comparison between the paleogeographic limits and identified Hercynian structures constitutes fresh evidence for reactivation of pre-existing Hercynian faults.

Key words: Paleogeographic, reservoir, tectonics, gravity, Rharb, Morocco

\section{Introduction}

The Rharb Basin of western Morocco belongs to the tectonic foreland of the Rifean Cordillera, which constitutes the southwestern edge of the Mediterranean Alpine chain. This Miocene-Pliocene basin (Cirac 1987) extends westward beneath the Atlantic Ocean (Malod and Mougenot 1979; Flinch 1996). Numerous paleogeographic studies led to the geometric reconstruction of the basin, and the

Addresses: L. Zouhri: 19 rue Pierre Waguet, BP 30313, F-60026 Beauvais Cedex, France,

e-mail: lahcen.zouhri@lasalle-beauvais.fr

D. Vachard, C. Lamouroux: USTL, UMR 8014 du CNRS, 59655 Villeneuve d'Ascq cedex, France

Received: June 11, 2007; accepted: January 20, 2008 
identification of reservoir units of importance for oil explorations and groundwater resources (Feinberg 1978, 1986; Cirac 1987; Wernli 1988; Flinch 1996). Establishing the paleogeographic limits was problematic - and still poses problems, in particular in the case of the Miocene-Pliocene sequences. Their reconstruction is based mainly on biostratigraphic identification of Globorotalia (Feinberg 1978) and on the interpretation of groundwater and oil wells. However, coring is expensive and was not carried out in all the wells drilled in the Rharb Basin. Moreover, the subhorizontal topography does not facilitate the study of the paleogeographic and structural changes. The systematic use of geophysical methods (reflection seismic) initially enabled us to delimit the reservoirs and to highlight the major structures within this basin (Zouhri et al. 2002). In the first part of this paper we will discuss the evolution of the coastline based upon the distribution of biozones with Globorotalia. We will then demonstrate that the overlaying of paleogeographic limits on the Hercynian structures provide new evidence recording fault activity during the Tortonian and the Plio-Quaternary sedimentation.

\section{Geologic and stratigraphic setting}

The Rharb Basin represents the southernmost edge of the structural units of the Rifean Cordillera (Fig. 1). To the north and the east it is limited by the PreRifean nappes. To the south the various formations of the basin overlie the Meseta, which shows a rigid and stable behavior. Gravimetric (Van den Bosch 1981) and well data show that the Paleozoic basement, outcropping in the Rabat area, deepens gradually from south to north. The stratigraphic columns of the Neogene deposits presented in this work were compiled from the data of the old oil surveys (Feinberg 1986; Wernli 1988, Flinch and Vail 1998) or of more recent vintage (MO1, SE1, EM1, SO1; Fig. 2a), in order to define the characteristics of the sequence. The Neogene sequence consists of Tortonian to Quaternary sediments that overlie either Cretaceous or allochthonous formations (the more or less chaotic Pre-Rifean complex [survey MO1]). The Paleozoic basement forms a north-south oriented depression; the Neogene series thickens in the same direction.

The Tortonian sequence is primarily made up of more or less sandy marl. According to the microfaunistic analyses (Feinberg 1986) this series shows the presence of Globorotalia miotumida dalii, which disappears in well MAM2 at a depth of $-350 \mathrm{~m}$, and in MAM1 at $-640 \mathrm{~m}$ (Fig. 2b). This local event corresponds roughly to the Miocene/Pliocene limit, which is at $-340 \mathrm{~m}$ in MAM2 and at -630 $\mathrm{m}$ in MAM1.

The thickness of the Plio-Quaternary deposits varies from $632 \mathrm{~m}$ in the southernmost part of Rharb to $1,200 \mathrm{~m}$ in the northern part. This series shows heterogeneous facies (sandstone, limestone, clay, marl, sand) and is of great interest for hydrogeologists, as it contains considerable water resources. The 


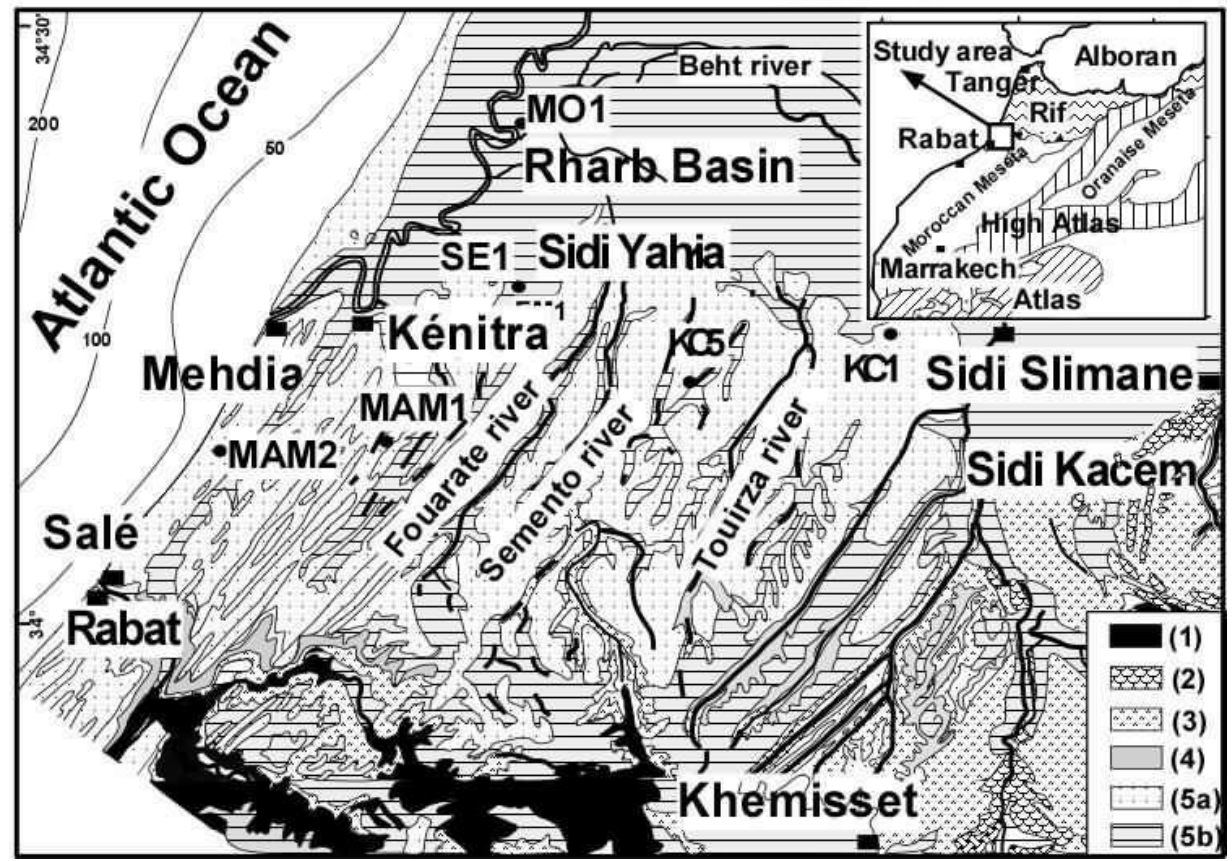

Fig. 1

Location and geology of the Rharb-Mamora basin. 1. Paleozoic, 2. Mesozoic (Middle and Upper Liassic, and Middle Jurassic), 3. Miocene (Tortonian), 4. Pliocene, 5. Quaternary: 5a. Marine and beach formations (Middle to Late Quaternary), 5b. Continental formations (Moghrebian, Villafranchian, early to late Quaternary), KC5. Oil wells

different thicknesses of the marine series of the Lower and Middle Pliocene are indicated in Table 1.

In both wells Miocene to Pliocene sedimentation is continuous and without lithological change. The deposits of the Pliocene sequences correspond to open marine facies, rich in planktonic foraminifera. This marine sedimentation, which ends in the Middle Pliocene, marks a regressive evolution, the shallow deposits of which are shaly sand and sandy marl, up to $20 \mathrm{~m}$ in thickness (MAM1). This phenomenon is less marked in MAM2 where sedimentation is fully marine.

Table 1

Thickness of biozones of the Pliocene series in the MAM1 and MAM2 wells

\begin{tabular}{|c|c|c|c|}
\hline Age & Zones & MAM1 (m) & MAM2 (m) \\
\hline Middle Pliocene moyen & Zone with Globorotalia crassaformis & 59 & 27 \\
\hline Middle Pliocene moyen & Zone with Globorotalia aemiliana & 38 & 30 \\
\hline Lower Pliocene inférieur & Zone with Globorotalia puncticulata & 412 & 185 \\
\hline Lower Pliocene inférieur & Zone with Globorotalia margaritae & 60 & 55 \\
\hline
\end{tabular}




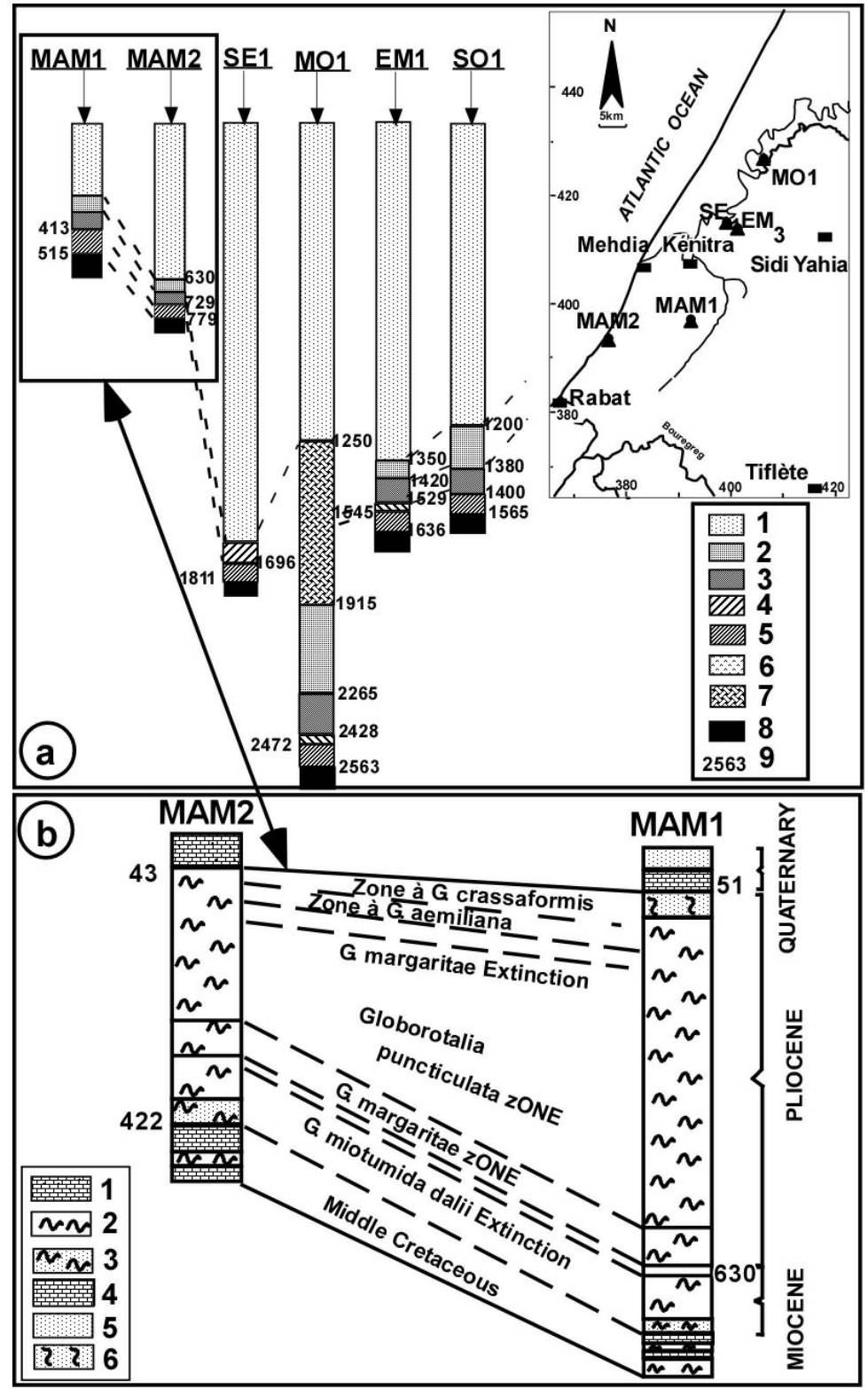

Fig. 2

a) Correlation between wells drilled in the Rharb basin: 1. Plio-Quaternary, 2. Late Miocene, 3. Early Miocene, 4. Late Cretaceous, 5. Middle Cretaceous, 6. Triassic, 7. Pre-Rifean Complex, 8. Paleozoic, 9. Depth (m)

b) Biozones of the MAM1 and MAM2 wells (after Feinberg, 1978, modified): 1. Sandy limestone, 2. Marl, 3. Sandy marl, 4. Dolomite, 5. Sand, 6. Coquina 
Feinberg (1986) concluded that part of this series could be eroded below the Quaternary deposits.

\section{Paleogeographic and structural evolutions}

The chronostratigraphic limits are established on the basis of the biozones identified by Feinberg (1986) and the interpretation of well data. The positioning of these limits demonstrates the westward migration of the marine shore. We will compare the evolution of the shorelines with the position of the Hercynian faults which were deduced from the reflection seismic data.

During the Tortonian most of the southern part of the Rifean Cordillera corresponded to a marine environment (Fig. 2a) controlled by the advancing PreRifean nappes (Fig. 3). A series crops out in the northern part of Souk El Arba, comprising a muddy fine sandstone alternation with sandy marl, of littoral or sublittoral facies.

The Tortonian-Messinian boundary is characterized by a detrital episode. Recurrences of marine sedimentation occurred during the Messinian, with a marked amplification of tectonic movement of Late Tortonian age, oriented in an east-west direction. The bathyal facies appears only at Rabat (Fig. 3b). Continuous subsidence characterized this part of this basin.

In the Early Pliocene, and during deposition of the sequence with Globorotalia margaritae, the eastern edge is marked by rare planktonic foraminifera and abundant benthic Elphidium and Ammonia species (Feinberg 1978), indicating shallow marine conditions. The presence of lignite and oysters in the outcrops of the eastern part of the gulf (e.g. in the valley of Beht) demonstrate the proximity of the shoreline. A regressive period corresponding to the zone with Globorotalia puncticulata is accompanied by active subsidence and landslide of the Pre-Rifean Complex to the southwest (Fig. 3c). The coastal zone seems to migrate close to Souk El Arba (southwestward movement) and close to Rabat (northward).

In spite of the weak Middle Pliocene local transgressions (Fig. 3d) the dimensions of the Atlantic gulf became smaller. The predominant facies is of littoral type, with shaly sands containing macrofauna to the north of Sidi Allal Bahraoui (Feinberg and Lorenz 1970). Water depth decreased, but subsidence remained active north of Kenitra and in the vicinity of the oil well MO1.

The bathyal gulf evolved through several stages involving the westward migration of the deformed at its eastern edge. Meanwhile, in the northern part of the basin, deformation in the Rharb Basin was advancing southward (Fig. 4a). The Mio-Pliocene is represented by marine blue marl deposits (Combe 1975) containing occasional sandy levels. The examined fauna and facies indicate that during the Early Pliocene, an open and calm environment was largely typical for the southernmost part of the Rharb Basin. The position of the coastal zone that is characterized by the presence of coquinas and coarse elements corresponds mainly to the actual position of the Beht River. The bathyal zone tended to move 


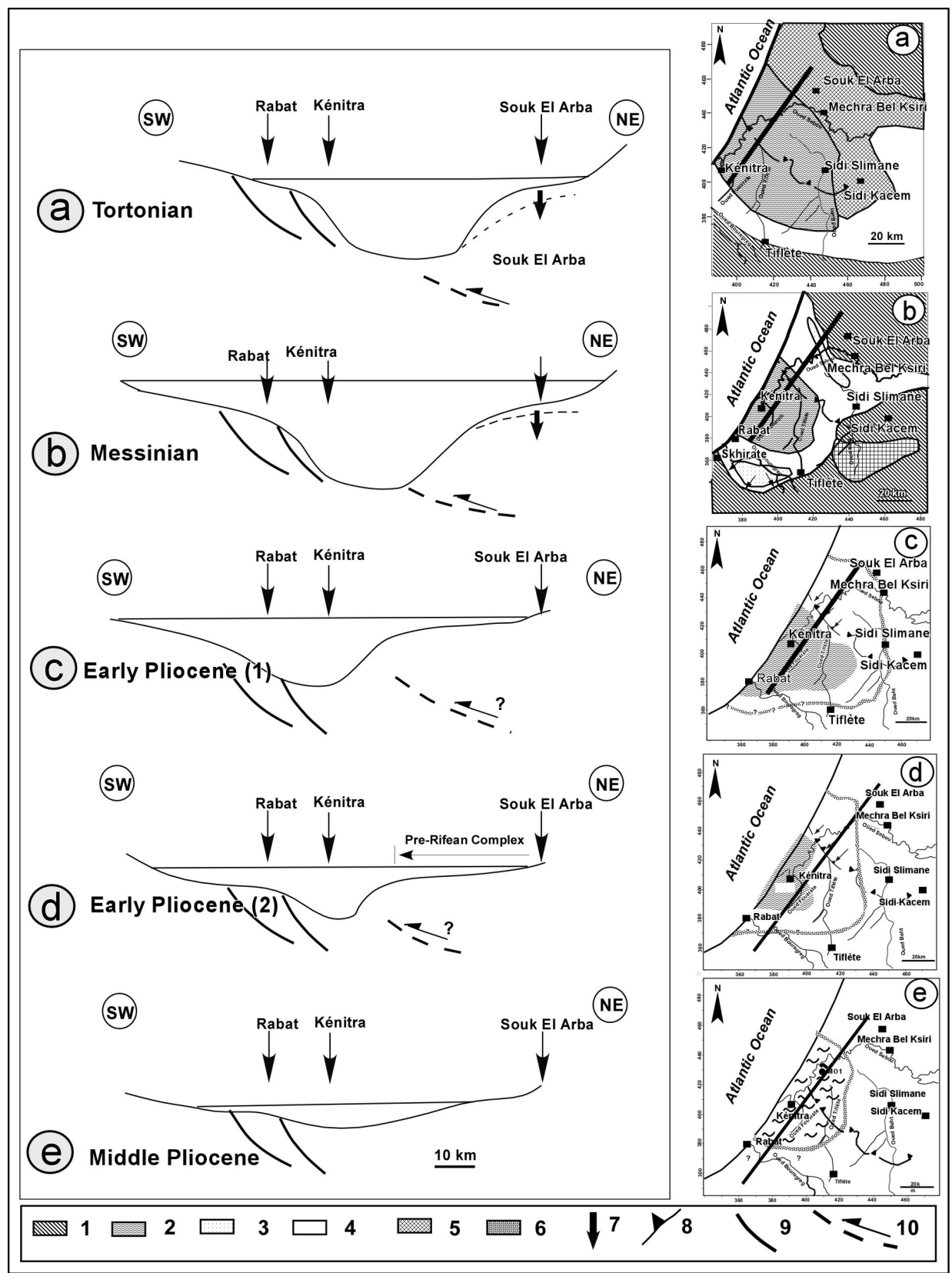

Fig. 3

Paleogeographic evolution of the Rharb basin with the interpretative sections: 1. Emerged domain 2. Bathyal facies, 3. Neritic facies, 4. Intermediate facies, 5. Subsiding zones, 6. Coastal limits, 7. Subsidence, 8. Front of nappes, 9. Faults, 10. Pre-Rifean Nappe 


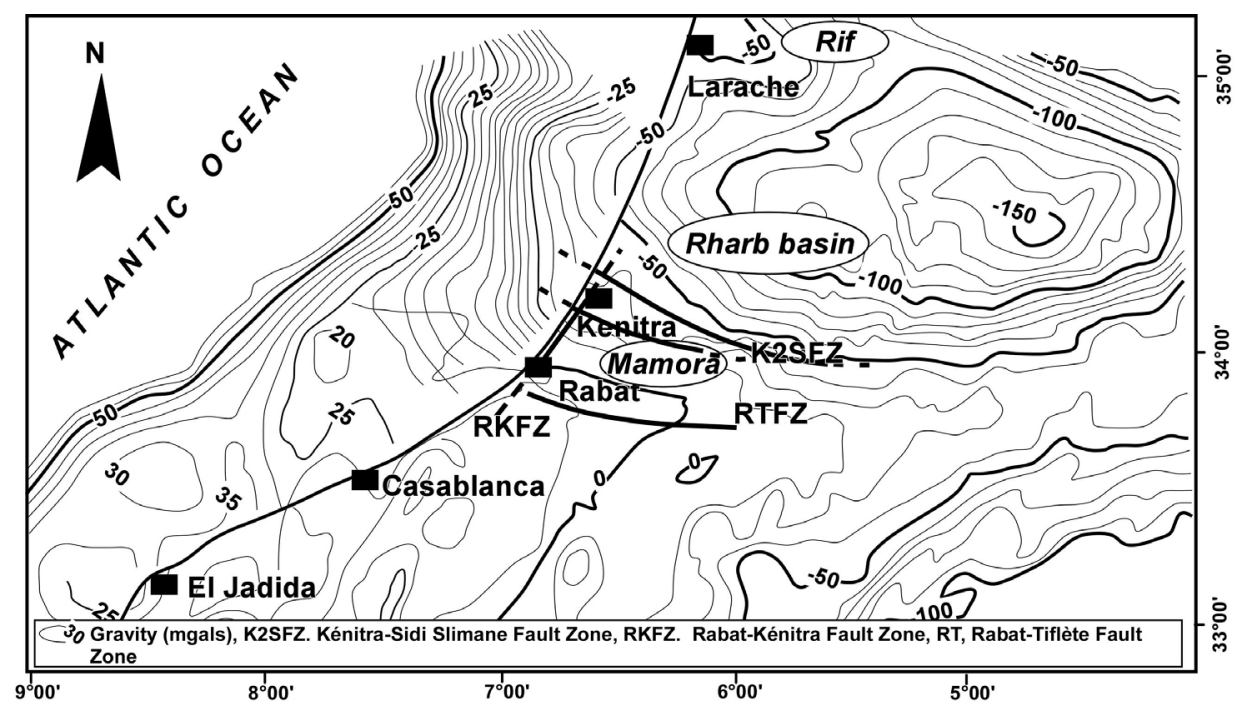

Fig. 4

Gravity anomaly map of the Rharb-Mamora Basin (Van Den Bosch JWH, 1981; Zouhri 2003, modified)

westward (the current Atlantic coast) during the Early and Middle Pliocene, marking a regressive phase.

The paleogeographic reconstruction of the Rharb Basin and the identification of the reservoirs were completed by geophysical interpretation based primarily on the analysis of seismic lines (Zouhri et al. 2002). Based on the analysis of seismic data, two important Hercynian structures were identified: the K2SFZ (Kénitra-Sidi Slimane Fault Zone) and the RKFZ (Rabat-Kénitra Fault Zone) (Fig. 4). They were correlated respectively to the Rabat-Tiflète Faulting Zone (RTFZ; Piqué 1982) and to the sheared, submeridian west-Mesetian zone, between the Coastal Mole and the Central Meseta (Rabat-Agadir; Piqué et al. 1980).

The K2SFZ was not only identified through seismic interpretation but also by other methods. The gravity data, which was studied by ONAREP (Office National de la Recherche et de l'Exploration Pétrolière, Rabat), shows an important negative gravity anomaly, which has been recorded in the Northwest Moroccan Atlantic, onshore Casablanca, north of Rabat and onshore across the Rharb-Mamora Basin (Fig. 4). The Rif and Pre-Rif domains constitute a major negative gravity anomaly on the Mediterranean coast. The Kenitra area represents the hinge between the positive and negative values. This gravity anomaly will be referred to as the Kenitra Gravity Anomaly (KGA) (ONAREP, unpublished). The Paleozoic basement is located north of Kenitra, at a depth of $2400 \mathrm{~m}$. It is very important to highlight the changes associated with the gravity data. Oriented E-W in the Kenitra-Sidi-Slimane area $\left(\mathrm{N} 140^{\circ} \mathrm{E}-\mathrm{N} 90^{\circ} \mathrm{E}\right)$, the orientation of the gradient becomes $\mathrm{N} 130^{\circ} \mathrm{E}$ and even $\mathrm{N} 030^{\circ} \mathrm{E}$ near Rabat. These 
gravity anomalies coincide with the Hercynian faults deduced from the interpretation of seismic reflection data: the Kenitra-Sidi-Slimane Fault Zone (K2SFZ) and the Rabat-Kenitra Fault (RKFZ). They have been studied by the Department of Geological Services of Morocco (Van Den Bosh 1981). Figure 5 shows the crustal models of the Atlantic coast. Extensive modeling (ONAREP, unpublished) demonstrated that the KGA could be explained by an abrupt thinning of the continental crust (density $2.67 \mathrm{gm} / \mathrm{cc}$ ) from the normal $30 \mathrm{~km}$ thickness to approximately $15 \mathrm{~km}$. Supra-crustal sediments thin to the north and their average density is $2.3 \mathrm{gm} / \mathrm{cc}$. Van Den Bosch (1981) postulates that this anomaly is caused by a marked suture zone, the Meseta Platform.

The principal structures deduced from seismic interpretation were superimposed on the map showing paleogeographic limits (Fig. 6b) in order to understand their relationships. Fault zone K2SFZ coincides with the Tortonian and Pliocene shorelines, showing the syn-sedimentary faulting influence. The geologic sections constructed across the Rharb Basin, in particular those from the southernmost part (Fig. 7), reveal a reservoir partitioned in horsts and grabens. This Hercynian fault (K2SFZ) was reactivated on several occasions, in particular during Mio-Pliocene times (Zouhri et al. 2002). During the Atlantic opening, the various faults facilitated the formation of basins, in depressions elongated in a more or less E-W direction (in the Coastal Mole, Meseta and Rharb). Major faulting exhibits a strong vertical component, creating the horst and graben structures in the southernmost part of Rharb. These faults are associated with a vast zone of sinistral east-west shearing (Laville and Piqué 1991).

\section{Discussion}

In the Rharb Basin the geometry of the various units is characterized by structural diversity (Flinch 1996; Zouhri et al. 2002). Seismic interpretations (Zouhri et al. 2003) show Plio-Quaternary permeable bodies which rest directly on grabens filled with Tortonian-Messinian sediments. These grabens were identified in the northern part of the Rharb, and were formed within the PreRifean Complex. On the other hand, in the southernmost part, the various grabens identified in particular from oil wells (at the level of MAM1 and MAM2; Fig. 2), are characterized by very thick Plio-Quaternary formations which rest on Mesozoic and Paleozoic series. These depressions are delimited by normal faults which affect the Plio-Quaternary hydrogeologic reservoir and the subjacent formations. Further north the top of the complex, the Tortonian-Messinian levels and the Pliocene cover are affected by normal listric faults with dominant N-S oriented direction (Flinch 1996). The Rharb Basin is thus marked by extensional as well as compressional structures (Fig. 8). In the Rif and in the Neogene Basin two major phases were identified: an extensional one, which lasted from the

Fig. $5 \rightarrow$

Crustal model of the Atlantic coast showing the calculated and observed Bouguer anomaly 
New evidence for Hercynian faulting in the southernmost margin of the Rharb Basin (Morocco) 79

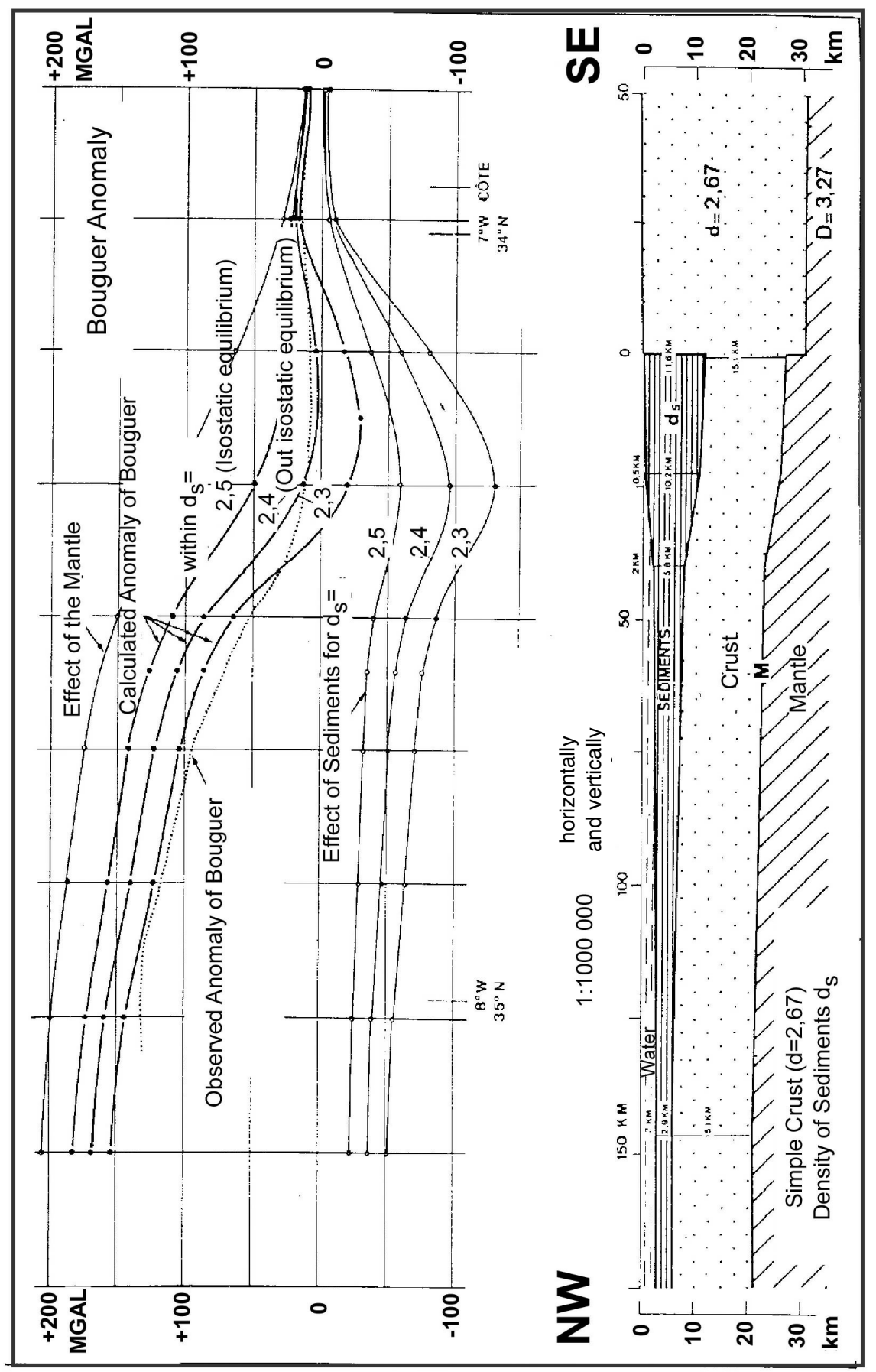

Central European Geology 51, 2008 


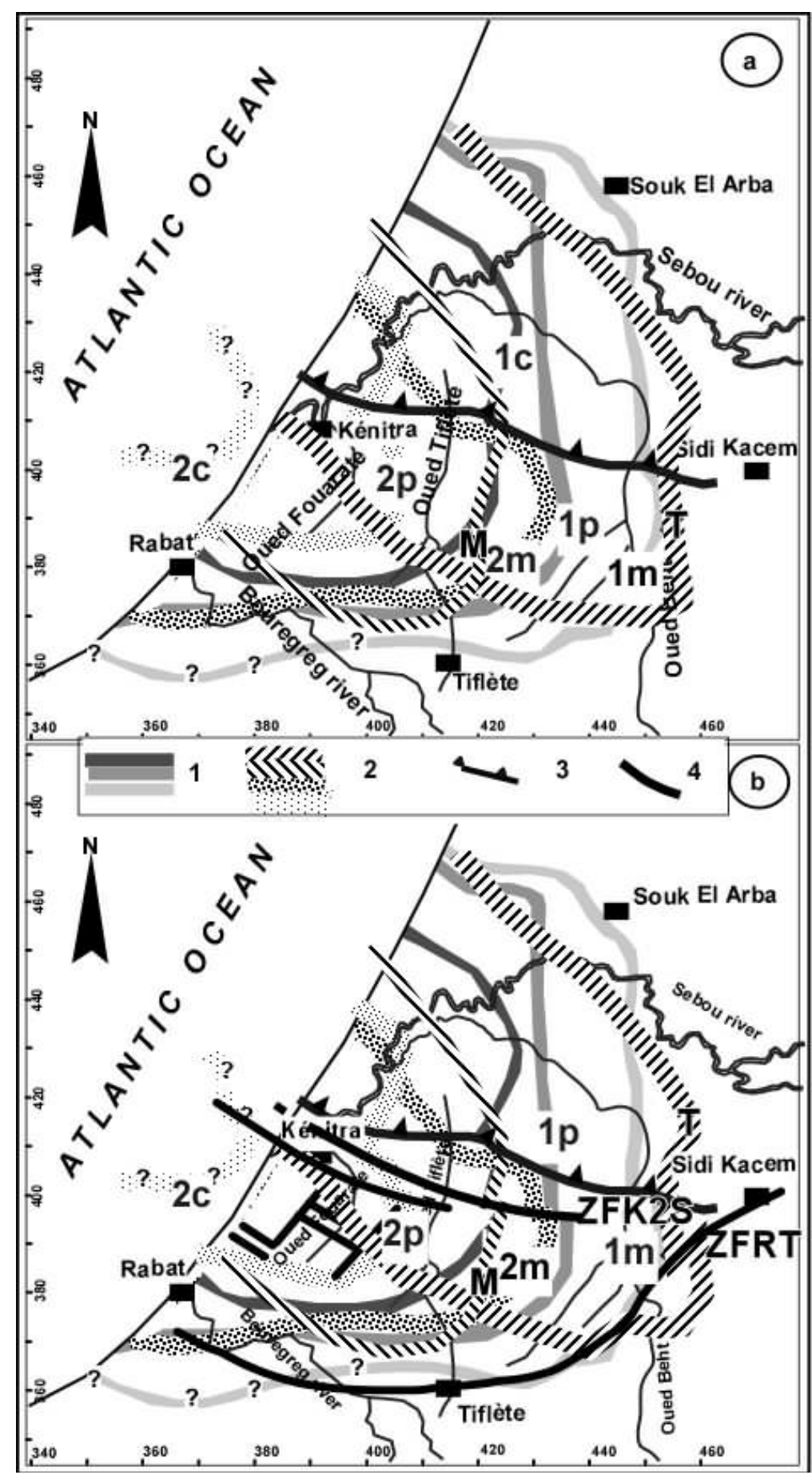

Fig. 6

a) Paleogeographic

evolution of the

Rharb Basin and b)

structural influence:

1. Coastal limit, 2.

Bathyal facies, 3.

Front of the nappe, 4 .

Faults (K2SFZ:

Kenitra-Sidi Slimane

Fault Zone, RTFZ:

Rabat-Tiflete Fault

Zone) $\mathrm{T}$ - Tortonian,

$\mathrm{M}$ - Messinian, $1 \mathrm{~m}$

and $2 \mathrm{~m}$. Globorotalia

margaritae biozone, $1 \mathrm{p}$

and $2 \mathrm{p}$. Globorotalia

puncticulata biozone,

1c and 2. Globorotalia

crassaformis biozone

Central European Geology 51, 2008 


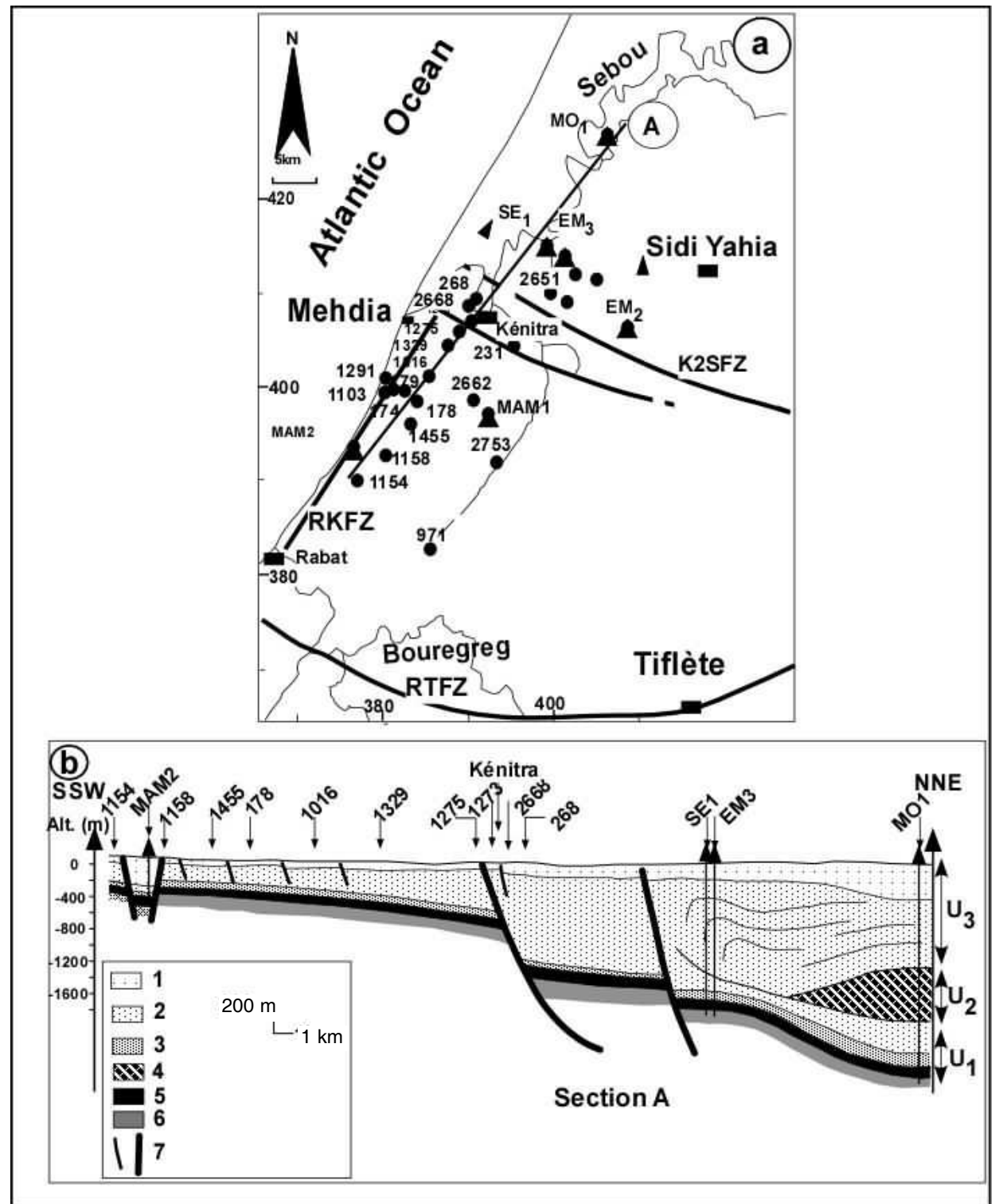

Fig. 7

a) Location and b) geologic section obtained from the combination of oil and water wells. 1. PlioQuaternary, 2. Late Miocene, 3. Early Miocene, 4. Pre-Rifean Complex, 5. Cretaceous, 6. Paleozoic, 7. Faults (after Zouhri et al. 2002; modified) 
Tortonian to the Messinian, followed by a compressional N-S oriented one during the Pliocene (Colletta 1977; Zizi 1996a, 1996b). The extensional phases were identified in the central Rif (Samaka et al. 1997), in particular in the subsiding Taounate Basin, during the same period. This phase is marked by normal synsedimentary normal faults of listric geometry, followed by Plio-Quaternary compression. The K2SFZ fault zone divides the Rharb into two sectors: i) a

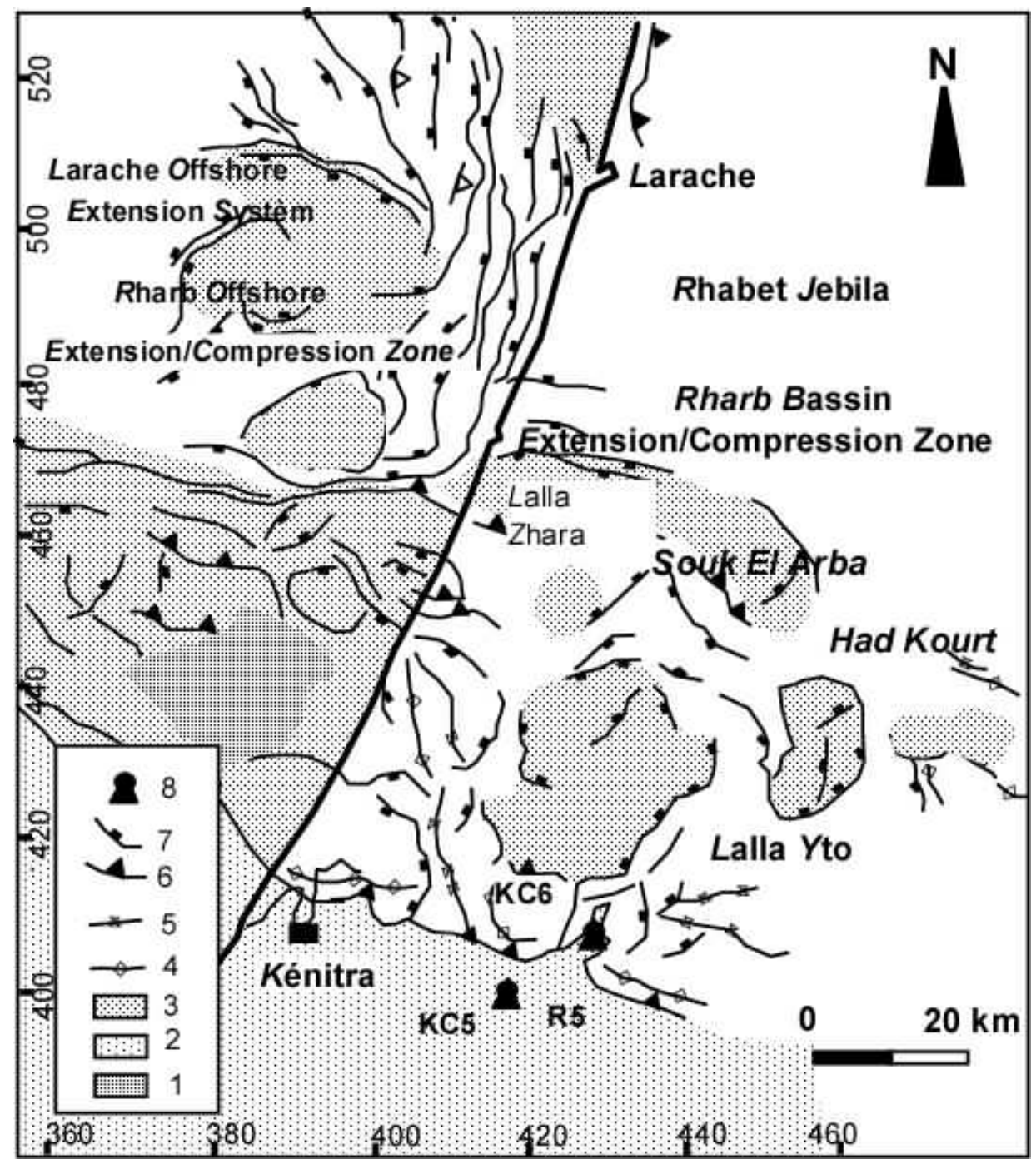

Fig. 8

Structural map of northwestern Morocco with the major structural domains (after Flinch 1996; modified): 1. Slumps, 2. Foredeep Basin, 3. Satellite Basin, 4. Anticline, 5. Syncline, 6. Thrust, 7. Extensional fault, 8. Oil wells 
northern part, where the Plio-Quaternary deposits are very thick; the grabens identified in this zone are not related to the reactivation of the Hercynian faults, but rather to the landslide of the Pre-Rifean Complex, and ii) a southern part, characterized by uplifted and subsided blocks, controlled by the counterpart of the Hercynian K2SFZ fault zone. The formation of these structures occurred in the course of Tortonian and Pliocene-Quaternary sedimentation.

\section{Conclusion}

The Pliocene-Quaternary reservoirs of the Rharb Basin are composed of various facies that rest upon Tortonian sediments. The paleogeographic evolution of this basin was marked by westward and southward migration of the bathyal limit. Active subsidence and landslide of the Pre-Rifean Complex contributed to the tectonics of the basin, in particular in its northern part. This tectonic evolution was controlled in the southernmost part of the basin by Hercynian faulting, reactivated between the Tortonian and the Pliocene-Quaternary.

\section{Acknowledgements}

The authors are grateful to Editor János Haas and the reviewer István Györfy for their helpful comments and suggestions on an earlier draft of this work.

\section{References}

Cirac, P. 1987: Le bassin sud-rifain occidental au Néogène supérieur. Evolution de la dynamique sédimentaire et de la paléogéographie au cours d'une phase de comblement. - Mém. Inst. Géol. Bassin d'Aquitaine, Bordeaux, 21, 287 p.

Colleta, B. 1977: Evolution néotectonique de la partie méridionale du basin de Guercif (Maroc oriental). - Thèse de 3ème cycle, Univ. Grenoble, 136 p.

Combe, M. 1975: Le bassin Rharb-Mamora et les petits bassins septentrionaux des oueds Dradère et Soueire. Ressources en eau du Maroc.T2. Plaines et bassins du Maroc atlantique. - Service Géologique. Maroc, pp. 93-128.

Feinberg, H. 1978: Les séries tertiaires des zones externes du Rif (Maroc). - Notes et Mémoire Service Géologique. Maroc, 315, pp. 1-192.

Feinberg, H. 1986: Les séries tertiaires du Prérif et des dépendances post-tectoniques du Rif. - Thèse d'Etat Sc. Nat. Univ. Toulouse, 211 p.

Feinberg, H., H.G. Lorenz 1970: Nouvelles données stratigraphiques sur le Miocene supérieur et le Pliocène du Maroc nord-occidental. - Notes et Memoires du Service Géologique du Maroc, 225, pp. 21-26.

Flinch, J.F. 1996: Accretion and extensional collapse of the external Western Rif (Northern Morocco). Peri-Tethys Memoir 2: Structure and Prospects of Alpine basins and Forelands. - Mém. Mus. Nat. Hist. Nat., 170, pp. 61-85 + Enclosures 1-2. Paris.

Flinch, J.F., PR. Vail 1998: Plio-Pleistocene sequence stratigraphy and tectonics of the Gibraltar arc. Mesozoic and Cenozoic Sequences. - Stratigraphy of European Basins, Society for Sedimentary Geology, Special Publications, 60, pp. 199-208.

Laville, E., A. Piqué 1991: La distension crustale atlasique au Maroc au début du Mésozoïque: le rejeu des structures hercyniennes. - Bull. Soc. Géol. France, 162/ 6, pp. 1161-1171. 
Malod, J., D. Mougenot 1979: L'histoire géologique néogène du Golfe de Cadix. - Bull. Soc. Géol. France, 21, pp. 603-611.

Piqué, A. 1982: La zone de Rabat-Tiflète (Méséta marocaine septentrionale). Sa place dans l'ensemble des noyaux paléozoïques de la Méditerranée occidentale. - Comptes Rendus de l'Académie des Sciences. Paris, 295, pp. 263-266.

Piqué, A., D. Jeannette, A. Michard 1980: The Western Meseta Shear Zone, a major and permanent feature of the Hercynian belt in Morocco. - Journal of Structural Geology, 1/2, pp. 55-61.

Samaka, F, A. Ben Yaich, M. Dakki, M. Hcaine, A.W. Bally 1997: Origine et inversion des basins miocènes supranappes du Rif central (Maroc). Etude de surface et de subsurface. Exemple des bassins de Taounate et de Tafrannt. - Geodinamica Acta, 10, pp. 30-40.

Van Den Bosch, J.W.H. 1981: Mémoire explicatif de la carte gravimétrique du Maroc (province du Nord). - Notes et Mémoires du Service Géologique du Maroc, 234, Ministère de l'Energie et des Mines, Direction de la Géologie, Rabat, Maroc.

Wernli, R. 1987: Micropaléontologie du Néogène post-nappes du Maroc septentrional et description systématique des foraminifères planctoniques. - Notes et Mémoires Service Géologique du Maroc, 331, 265 p, Rabat.

Wernli, R. 1988: Micropaléontologie du Néogène post-nappes du Maroc septentrional et description systématique des foraminifères planctonique. - Notes et Mémoires Service Géologique du Maroc, 331, $270 \mathrm{p}$.

Zizi, M. 1996a: Triassic-Jurassic extensional systems and their Neogene reactivation in Northeastern Morocco (the Rides Prerifaines and Guercif basin). - Ph. D. Thesis, Rice University, 280 p.

Zizi, M. 1996b: Triassic-Jurassic extension and Alpine inversion in Northern Morocco. - In: Ziegler, P.A., F. Horváth (Eds): Peri-Tethys Memoir 2: Structure and prospects of Alpine basins and Forelands. Mémoire Muséum National Hist. Nat. Paris, 170, pp. 87-101.

Zouhri, L., C. Gorini, C. Lamouroux, D. Vachard, M. Dakki 2003: Interprétation hydrogéologique de l'aquifère des bassins sud-rifains (Maroc): apport de la sismique réflexion. - Comptes Rendus Géoscience. Paris, Série II, 335, pp. 319-326.

Zouhri, L., C. Lamouroux, D. Vachard, A. Piqué 2002: Evidences of flexural extension of the Rif Foreland: the Mamora Area (Northern Morocco). - Bulletin de la Société Géologique de France. 173/6, pp. 509-514. 